\title{
Corporate Social Responsibility Activities that Influence Customer Loyalty of SMEs
}

\author{
Peter K. Turyakira ${ }^{1}$ \\ ${ }^{1}$ Department of Marketing and Management, Makerere University, Uganda \\ Correspondence: Peter K. Turyakira, Department of Marketing and Management, Makerere University, Uganda. \\ E-mail: pturyakira@gmail.com
}

Received: March 6, 2018

doi:10.5539/ijbm.v13n6p255
Accepted: May 3, 2018

Online Published: May 15, 2018

URL: https://doi.org/10.5539/ijbm.v13n6p255

\begin{abstract}
Businesses are increasingly required to address the demands of key stakeholders, in addition to those of shareholders. There is an increasing role of corporate social responsibility (CSR) to large businesses and small and medium enterprises (SMEs) alike. However, research to support the degree of the application of CSR activities to SMEs with respect to customer loyalty is limited. The purpose of this study was to examine the selected CSR activities that impact the customer loyalty of SMEs. A self-administered questionnaire was distributed to selected SMEs in Kampala District, while Structural Equation Modeling was utilised to determine the influence of independent variables on the dependent variable. The study findings revealed that the selected CSR activities (Society-oriented CSR activities, Market-oriented CSR activities and Environmental-oriented CSR activities) positively influence the Customer loyalty of SMEs.
\end{abstract}

Keywords: corporate social responsibility factors, customer loyalty, small and medium enterprises

\section{Introduction}

Small and medium enterprises (SMEs) are seen as critical for economic growth of many countries globally (Ayanda \& Laraba, 2011, p. 200; Bellihi \& Bazi, 2015, p. 340). SMEs have increasingly gained wide recognition by creating employment opportunities, income generation, poverty reduction and improving standards of living of people especially in developing countries (Munasinghe \& Malkumari, 2012, p. 168; Ngui, 2014, p. 461; Tushabomwe; 2010; Tusubura \& Nabeta, 2013, p. 133). Despite their growing importance, the high failure rate of SMEs, particularly in developing countries, is a cause for concern (Turyakira, 2012, p. 1). Businesses can adopt CSR activities to influence the behaviours of consumers to achieve customer loyalty (Asatryan, 2012, p. 66; Yusof, Manan, Karim \& Kassim. 2015). Businesses which embrace the concept of CSR are likely to attract customers and influence their loyalty to develop positive attitudes towards their products, thus gaining better financial performance and positive publicity (Ochoti, Muathe, Ronoh, Maronga, \& Ochoti, 2013, p. 161). As such, SMEs can participate in CSR activities as a way to generate customer loyalty (Bhattacharya, \& Sen, 2004; Raman, Lim \& Nair, 2012, p. 72; Stanisavljević, 2017, p. 40; Yusof et.al, 2015, p. 112). Although the notion of CSR has been well investigated in large organisations over the years (Adapa \& Rindfleish, 2013, p. 82), few studies have been conducted in the domain of SMEs (Adapa \& Rindfleish, 2013, p. 82; Castejón \& López, 2016, p. 21).

Many businesses have increasingly realised the significance of CSR and its influence on the well-being of society (Raman et al., 2012, p. 72). As such, a number of them has increasingly accepted to voluntarily behave socially responsible to enhance their customer loyalty (Hsueh, 2012, p. 1). Consumer loyalty is viewed as an aspiration for customers to continue conducting affairs with particular businesses (Chaffey, 2008) through social contributions (Grant, 2000). Previous studies (Asaad, 2010; Saunders, 2006; Pakseresht, 2010; Yusof et.al, 2015, p. 113) have revealed that if well implemented, CSR initiatives could enhance the customer loyalty of SMEs. Similarly, CSR activities can positively influence SMEs' reputation and result in a better customer loyalty (Mandl, 2009; Szabo, 2008; Yusof et.al, 2015, p. 113). According to Arıkan and Güner (2013), CSR campaigns can contribute to the creation of customer loyalty. As such, CSR can influence customer loyalty in a positive and significant way (Mandhachitara \& Poolthong, 2011).

Despite the growing attention to CSR, studies regarding the influence of CSR activities on SMEs limited, particularly in developing countries (Burton \& Goldsby, 2009; Castejón \& López, 2016, p. 22; Cilberti, 
Pontrandolfo, \& Scozzi 2008; Nejati \& Amran, 2009, p. 259). Similarly, academic literature on what motivates SMEs to participate CSR is inadequate, especially quantitative studies (Nejati \& Amran, 2009, p. 261). It is not clear the extent to which CSR factors influence customer loyalty in SMEs (Raman et al., 2012, p. 72). There is limited data with regard to CSR factors and their impact on customer loyalty of SMEs particularly in Uganda. Therefore, the purpose of this study was to investigate the impact of selected CSR activities on the customer loyalty of SMEs. Based on the results of the study, specific CSR activities that could enhance the customer loyalty of SMEs were recommended.

In this study, SMEs are viewed as businesses which employ a minimum of 5 but less than 100 persons, while customer loyalty is viewed as a business with satisfied customers who are ready to continuously patronize the business and recommend it to other customers. First, a theoretical overview is presented culminating into a proposed hypothesised model of the impact of selected CSR-oriented elements on Customer loyalty. Relevant hypotheses are also formulated and operationalised. Subsequently, the research design is explained while empirical results are deliberated on. Lastly, limitations are presented while highlighting opportunities for future research.

\section{Theoretical Overview}

\subsection{Clarification of Key Concepts: CSR and SMEs}

There has been increased recognition and appreciation of the social concerns by society and customers over the years. As such, businesses are expected to adopt and actively participate in socially responsible activities (Pirithiviraj \& Kajendra, 2010, p. 107; Stanisavljević, 2017, p. 40). According to Baker (2001), CSR activities can influence society in major areas such as workplace, marketplace, community and the environment. SMEs generally participate in few CSR-based activities that include maintaining sustainable customer relationships, extending their support to community-based activities and focusing on environment protection (Adapa \& Rindfleish, 2013:86; Stanisavljević, 2017, p. 40).

It has been recognised that CSR activities that are essential to large businesses, can also be significant to SMEs (Nejati \& Amran, 2009:259). There is also some evidence that links CSR to customer loyalty (Raman et al., 2012, p. 72). As such, business's CSR activities are likely to improve its reputation and customer loyalty (Raman et al., 2012, p. 75). CSR related activities can help a business attract more customers and enhance their loyalty (Longinos \& Salvador, 2007; Stanisavljević, 2017, p. 41). Hence, customer loyalty can be viewed as the degree to which consumers associate themselves to a business, which results in continuous buying behaviour (Chaffey, 2008; Kotler and Armstrong, 2008). According to Raman et al. (2012, p. 72), businesses which participate in CSR activities are likely to improve customer loyalty towards products. CSR factors with positive customer outcomes, such as loyalty, have lasting positive effects on customers (McDonald and Rundle-Thiele, 2008, p. 10; Stanisavljević, 2017, p. 41).

\subsection{Proposed Hypothesised Model and Hypotheses}

The conceived model in Figure 1, elucidates the influence of the selected CSR activities as independent variables on Customer loyalty as dependent variable.

Independent variables

\section{Dependent variable}

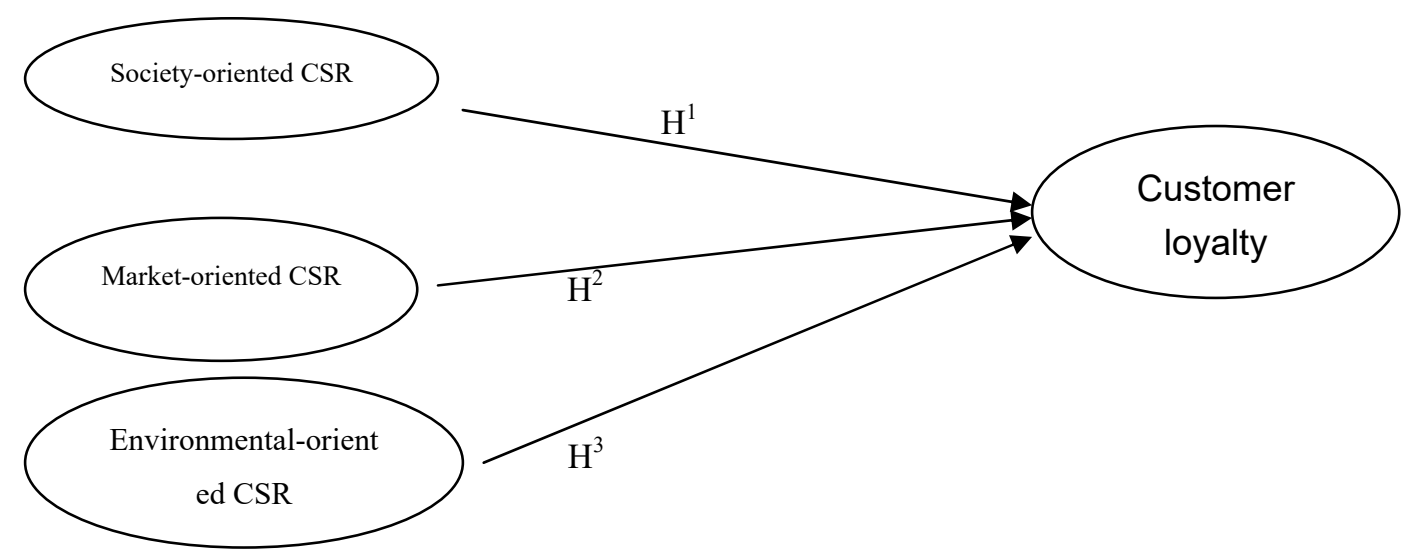

Figure 1. CSR activities impacting customer loyalty of SMEs

Independent variables: CSR factors. 
As demonstrated in Figure 1 above, independent variables are Society-oriented, Market-oriented and Environment-oriented CSR activities. These CSR factors are common to SMEs and are discussed in the subsequent sub-sections.

\subsection{Society-Oriented CSR activities}

Businesses, regardless of size, are considered part of society and their continued existence hinges on it. The society correspondingly imposes certain responsibilities on the businesses to discharge. As such, businesses are expected to voluntarily embrace CSR-related activities in addition to profit maximisation (Inyang, 2013, p. 123). Hence, businesses must develop and maintain close relationships with the key stakeholders in their operations, Society-related CSR activities refer to business actions including donating items to the needy in society, participating in community schemes and funding some community projects. As such, society-oriented CSR activities are about promoting social and harmonious existence in the society (European Commission, 2005; Stanisavljević, 2017, p. 42). Such activities should support and contribute to socio-economic development (Inyang, 2013, p. 124). According to Grewal (2012), society-oriented CSR activities involve a number of activities that businesses undertake to maximise their influence on the communities. Customers want to spend money in those businesses which are somehow involved in social welfare activities (Grewal, 2012). Hence, they can appraise a business on the basis of its consistent support to the community well-being (Kumar \& Priyadharshini, 2013, p. 278).

SMEs can support the local communities through benevolent activities as a strategy to retain their customers (Putnam, 2000). Hence, SMEs can use society-oriented CSR activities as a marketing tool to maintain the loyalty of their customers (Perrini \& Minoja, 2008). Furthermore, society-oriented CSR activities can improve the image of the business thereby appealing to new customers with the view of gaining their loyalty (Branco \& Rodrigues, 2006). For instance, an empirical study of SMEs Czech Republic (Polášek, 2010, p. 140) revealed that SMES which were engaged in selected Society-oriented CSR initiatives had gained and improved the loyalty of both internal and external customers. Similarly, a survey of SMEs in Italy (Longo, Mura \& Bonoli, 2005, p. 9) showed that they had improved customer retention because of their commitment to participating in CSR activities. Consequently, the following hypothesis is established:

$H^{l}$ : There is a positive significant relationship between Society-oriented CSR activities and Customer loyalty of the SMEs.

\subsection{Market-Oriented CSR activities}

Market-oriented CSR activities are viewed as activities in which a firm quickly responds to its customers' needs, provides them with useful information and generates profit without cheating the customers. Such activities include responsible advertising, professionally handling customer complaints and operating ethically.

The main market-oriented CSR activities entail ethical business practices; cordial consumer relationships; and participation of consumers in vital business decisions (European Commission, 2005, p. 42). It has become necessary for SMEs to embrace CSR as a strategy to achieve the socio-economic desires of their customers (Pirithiviraj \& Kajendra, 2010, p. 107).

By focusing on market-oriented CSR activities, SMEs can introduce different ideals, increase their status and design better quality goods and services that exceed expectations of their customers more effectively and efficiently, thus enhancing customer loyalty (Stoian \& Gilman, 2012). The implementation of market-oriented CSR activities is likely to generate a trusting relationship between the business and its customers thus making customers more committed to and developing loyalty to the business (Hafeez \& Muhammad, 2012; Kang \& Hustvedt, 2014; Maignan \& Ferrell, 2004; Sen, Bhattacharya, \& Korschun, 2006). A study conducted on SMEs in Czech Republic (Polášek, 2010, p. 138) discovered that SMEs customers had developed more loyalty due to the benefits derived market-oriented CSR activities. Relatedly, SMEs which implement market-oriented CSR activities are likely to increase their reputation and retain more customers (Ali et al., 2010, p. 477). Based on the facts presented above, it can be hypothesized that:

$H^{2}$ : Market-oriented CSR activities positively impact Customer loyalty of the SMEs.

\subsection{Environmental-Oriented CSR Activities}

These are viewed as activities that a firm adopts to reduce its harmful effect on physical environment. Environment-related CSR activities include ecological utilisation of natural resources, responsible packaging, minimising waste, pollution control as well as protection of the natural environment. They are also viewed as the actions of a business on ecosystems, air and water (Cabeza García et al.; 2014). As such, the common environmental-oriented CSR initiatives include depletion of resources and energy, as well as appropriate 
management of pollution and waste (European Commission, 2005, p. 33). For the purpose of this study, Environmental-related CSR activities refers to how a firm gets involved in creating environmental awareness campaigns, funding cultural and sports events and undertaking to minimising waste. It involves those actions a business may undertake to reduce its adverse influence on environment. Such actions may include responsible utilisation of resources, proper packaging and protection of the natural environment.

Research on European SMEs indicated that environmental-oriented CSR initiatives include designing ecologically usable products and active engagement in reprocessing actions (Mandl and Dorr, 2007, p. 47). Relatedly, the research results of Czech SMEs (Polášek, 2010, p. 141) showed that SMEs which implement environmental-related CSR activities can attract environmentally-conscious customers; protect their resources; and minimise operational outlays. Kassins and Soteriou (2003, p. 13) also confirm that there is a significant association between ecological practices and customer loyalty. As such, the benefits that can be derived from environmental practices include decreasing operational costs, prospects for improvement and customer loyalty. Based on the discussion above, it can be concluded that:

$H^{3}$ : There is a significant positive relationship between Environmental-oriented CSR activities and Customer loyalty of the SMEs

\subsection{Dependent Variable: Customer Loyalty}

Customer loyalty refers to customers' commitment to consistently purchase certain products or brands from specific businesses over time thereby building strong relationship with the organization (Maheshwari, Lodorfos, \& Jacobsen, 2014, p. 16). In today's competitive environment, customer loyalty has become more important for many businesses, especially SMEs (Rehman, 2012, p. 183). Accordingly, businesses have gradually moved from satisfying customers to making them loyal. Given the competitive environment in which businesses operate in, establishing lasting relationships with customers is fundamentally important (Rehman, 2012, p. 183). Today, many businesses are developing policies and strategies to maintain a loyal customer base (Cengiz, Ayyildiz, \& Er, 2007, p. 63; Hafeez \& Muhammad, 2012). As such, businesses have invested considerably in many programmes, including CSR activities, to attract and retain customers (Lam \& Burton, 2006, p. 38). Therefore, for the purpose of this study, Customer loyalty is viewed as a business having satisfied customers willing to consume and recommend its products but also committed to continuously buying its products over time.

Various scholars greatly differ on the measures of customer loyalty. A study by Lee, Lee \& Feick (2001, p. 6) established that customer loyalty is measured in terms of repeat purchases and reluctant to switching to competitors' products. Relatedly, previous research results (Brimpong, 2008, p. 60) revealed the dimensions of customer loyalty which include length of stay; the readiness to recommend a business's products to associates; and repurchase of a business's products. Certainly, research findings by Gable, Fiorito \& Topol (2008, p. 14) revealed that keeping the current customers is more cost effective than acquiring new ones.

Many studies have linked CSR activities to customer loyalty (Raman et al., 2012, p. 71). As such, a business can improve consumer loyalty by voluntarily engaging in social activities (Grant, 2000). Research findings in New Zealand (Singhal, 2013, p. 79) revealed that switching hurdles have a great influence on customer loyalty. Effecting CSR activities can benefit a business in terms of customer loyalty (Singhal, 2013, p. 81). According to Pirsc, Gupta \& Grau (2007), CSR activities lead to increased customer loyalty and repurchase intentions.

\section{Methodology}

\subsection{Population}

This study is based on an estimated population of over 1.5 million SMEs in Uganda (Mbabazi, 2012).

\subsection{Sampling}

Respondents were selected with the use of purposive sampling, particularly judgmental sampling, from various business sectors in in Uganda, particularly Kampala Disctrict, considering those with a workforce ranging from 5-100 employees (Uganda Bureau of Statistics- UBOS 2007). Thus, this study considered SMEs which employ more than 5 but fewer than 100 people.

\subsection{Scale Development}

Each factor under the examination was investigated using dependable and usable items acquired from validated questionnaires used by earlier scholars as indicated in Table 1 below. Some statements were rearticulated to make them appropriate for this particular study. Then items were subsequently utilised to test the correlations illustrated in the model. The questionnaire entailed two parts. Section one comprised 60 questions about to CSR related activities that impact SMEs' customer loyalty. These were based on a seven-point Likert-type interval 
scale. The second part of the instrument solicited personal profiles of respondents.

Table 1. Sources of earlier validated items utilised in the measuring instrument

\begin{tabular}{ll}
\hline Factors & References \\
\hline Society-oriented CSR activities & Chen (2009, p. 5), Grewal (2012), Herpen, Meulenberg \& Pennings, \\
& (2003, p. 19), Inyang (2013, p. 123), Stanisavljević (2017, p. 42). \\
Market-oriented CSR activities & Aqueveque \& Ravasi (2006, p. 37), Chen (2009, p. 5), Hafeez \& \\
& Muhammad (2012), Kang \& Hustvedt (2014) and Stoian \& Gilman \\
& $(2012)$. \\
Environmental-oriented CSR activities & Cabeza Garcíaet at., 2014) and Chen (2009, p. 5). \\
Customer loyalty & Donnelly (2009, p. 289), Maheshwari, et al., (2014:16), Ouyang (2010, \\
& p. 6), Raman et al., 2012, p. 71); Ramzi \& Mohamed (2010, p. 5), and \\
& Singhal (2013, p. 81). \\
\hline
\end{tabular}

\subsection{Data Collection}

Data were obtained from secondary and primary sources respectively. A literature search was done with the view of identifying appropriate CSR activities that have an influence on the customer loyalty of SMEs. The review covered journal articles, online reports and government documents. The primary data was collected from various industrial sectors in Kampala District in Uganda. Only those sectors with a workforce ranging from 5-100 employees were considered, and self-administered questionnaires were utilised for data collection. Consequently, 750 questionnaires were made available to potential respondents whereby 383 usable questionnaires were obtained, which constituted a response rate of $51 \%$.

\subsection{Data Analysis}

In this study, Analysis of Variance was utilised to evaluate the impact of demographic profiles. This was followed by conducting an exploratory factor analysis and Cronbach-alpha coefficients were calculated to assess the discriminant validity and reliability of the instrument respectively. Thereafter, the relationships were assessed using Structural Equation Modelling (SEM). Factor analysis was conducted to ascertain the representative variables and to create new constructs, using SPSS 18 version.

\subsection{Sample Description}

Demographic profiles showed that the large number of respondents were males $(63 \%)$ having been in operation for three to five years. Relatedly, a large percentage of respondents $(85 \%)$ were managers whose highest education level was a Diploma $(60 \%)$. Furthermore, a large number of respondents $(67 \%)$ ran private limited companies with a workforce of 11 to 20 full-time employees. It is important to note that $49 \%$ of the respondents were unwilling to provide details of their annual turnover. Nevertheless, $26 \%$ of respondents revealed that their annual turnover was below UGX 50 million (ZAR 161,290) per annum.

\section{Empirical Results}

\subsection{Discriminant Validity and Reliability}

In this study, SPSS 18 for Windows was utilised to conduct an exploratory factor analysis to establish the discriminant validity amongst the study constructs. On the basis of relational nature of the constructs, principal axis factoring with an oblique was ascertained as the extraction and rotation method for six sub-models. It should be noted that the exploratory factor analysis could not ratify all the latent constructs as initially expected in this study. As such, only items measuring Market-oriented CSR factors loaded as expected (see Table 2). 
Table 2. Rotated factor matrix: CSR factors

\begin{tabular}{llll}
\hline Item & Factor 1 & Factor $\mathbf{~}$ & Factor 3 \\
\hline MCA7 & $\mathbf{0 . 6 9 9}$ & 0.120 & 0.040 \\
MCA1 & $\mathbf{0 . 6 9 3}$ & 0.030 & 0.079 \\
MCA5 & $\mathbf{0 . 6 8 0}$ & 0.221 & -0.087 \\
MCA2 & $\mathbf{0 . 6 6 7}$ & 0.200 & 0.054 \\
MCA3 & $\mathbf{0 . 6 6 1}$ & -0.012 & 0.161 \\
MCA4 & $\mathbf{0 . 6 4 3}$ & -0.014 & 0.082 \\
MCA10 & $\mathbf{0 . 6 0 7}$ & 0.065 & 0.015 \\
ECA3 & 0.119 & $\mathbf{0 . 8 6 8}$ & 0.160 \\
SCA1 & 0.070 & $\mathbf{0 . 8 2 7}$ & 0187 \\
ECA2 & 0.206 & $\mathbf{0 . 7 7 0}$ & 0.037 \\
SCA7 & 0.052 & 0.159 & $\mathbf{0 . 7 1 6}$ \\
SCA5 & 0.075 & 0.078 & $\mathbf{0 . 7 0 1}$ \\
SCA2 & 0.067 & 0.068 & $\mathbf{0 . 6 2 8}$ \\
Eigen values & 4.452 & 2.160 & 1.061 \\
\% of Variance & 24.733 & 12.002 & 5.896 \\
Cumulative \% & 24.733 & 36.735 & 57.987 \\
\hline
\end{tabular}

Of all the items envisioned to assess Environmental-oriented CSR factors, only two items (ECA3 and ECA2) loaded together on this construct and the name for this factor remains unchanged. Relatedly, an item initially anticipated to measure Society-oriented CSR factors loaded on Environmental-oriented CSR factors (SCA1). This left three items which loaded on the Society-oriented CSR activities.

It should be noted that factor loadings of 0.30 and 0.40 are deemed important for sample sizes of 200 and 350 (Hair, Black, Babin, Anderson \& Tatham, 2006). As such, factor loadings of $\geq 0.4$ were observed for all items. Consequently, Cronbach-alpha coefficients of larger than 0.70 (Suhr \& Shay, 2009) were attained for all variables, establishing the credibility of scales of measurement. Table 3 below provides working descriptions of the factors as well as facts about the cogency and consistency of the research instrument.

Table 3. Research instrument analyses

\begin{tabular}{|c|c|c|c|}
\hline Operationalisation of factors & Items & $\begin{array}{l}\text { Factor } \\
\text { loadings }\end{array}$ & Cronbach-alpha \\
\hline $\begin{array}{l}\text { Market-oriented CSR activities refer to how a business handles consumers' requirements } \\
\text { quickly with regard to their orders and welfare by opening at appropriate times, treating them } \\
\text { justly, charging reasonable rates and generating revenue without cheating customers. }\end{array}$ & 7 & $\begin{array}{l}\text { Max:0.699 } \\
\text { Min: } 0.607\end{array}$ & 0.800 \\
\hline $\begin{array}{l}\text { Environmental-oriented CSR activities refer to how a business participates in leading and } \\
\text { funding environmental awareness campaigns, sports and cultural events and endeavouring to } \\
\text { minimise waste. }\end{array}$ & 3 & $\begin{array}{l}\text { Max: } 0.868 \\
\text { Min: } 0.770\end{array}$ & 0.804 \\
\hline $\begin{array}{l}\text { Society-oriented CSR activities refer to how a business participates in community activities by } \\
\text { funding projects, assisting the needy and sharing some of its proceeds with the community. }\end{array}$ & 3 & $\begin{array}{l}\text { Max: } 0.716 \\
\text { Min: } 0.628\end{array}$ & 0.758 \\
\hline
\end{tabular}

\subsection{Structural Equation Modelling Results}

Different fit indices were utilised to measure the degree to which the suggested model constitutes satisfactory estimation of information. These comprise the Satorra-Bentler scaled Chi-square $(\chi 2)$, the percentage of Chi-square to degrees of freedom ( $\chi 2 / \mathrm{df}$ ), RMSEA, and the $90 \%$ confidence interval for RMSEA (Hoe, 2008). It was confirmed that the indices provide evidence of a model with a thorough fit. The findings (see Figure 2) confirm that Society-oriented CSR activities, Market-oriented CSR activities and Environmental-oriented CSR activities substantially impact Customer loyalty of SMEs. 


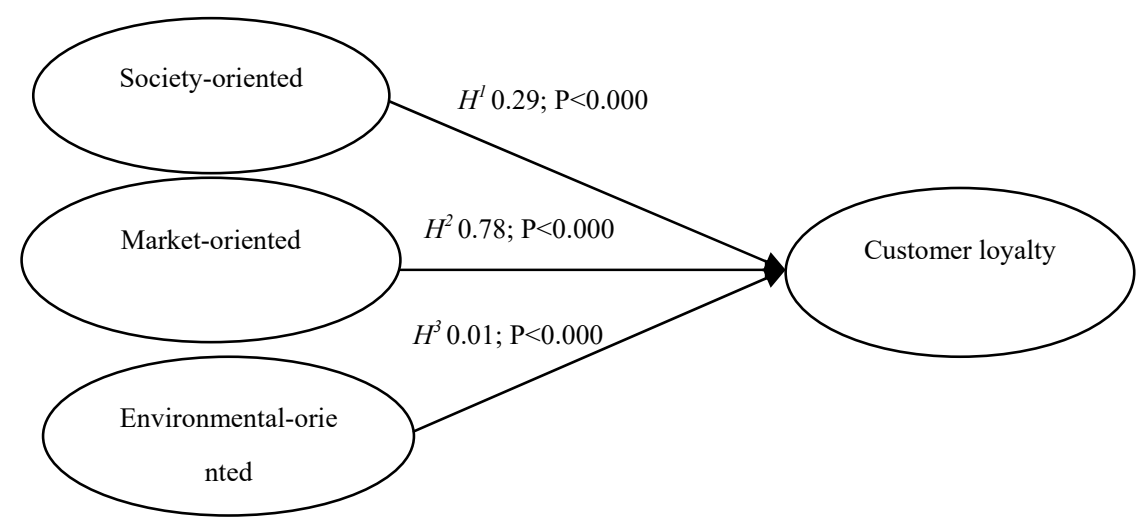

Figure 2. Empirical findings of CSR factors impacting customer loyalty of SMEs

\section{Interpretation of Research Findings}

It should be noted that in Figure 2 above, only the positive significant correlations identified by SEM are depicted. The empirical results of this study therefore reveal a significant correlation (path coefficient $=0.29 ; \mathrm{P}<$ 0.000) between Society-oriented CSR factors and Customer loyalty of SMEs. Hence, support was found for Hypothesis $H^{l}$. This implies that the respondents in this study are of the view that the more SMEs engage in community initiatives, the more likely they will attract and maintain consumers compared to those that are unwilling participate in community activities. This evidence supported by previous studies. For instance, an investigation of the Czech SMEs (Polášek, 2010, p. 140) revealed that SMEs which engaged in Society-oriented CSR initiatives improved the allegiance and commitment of consumers to their products and the business. Additionally, an empirical study of Italian SMEs by Longo et al., 2005, p. 9) indicated that the loyalty of their customers improved because of their involvement in CSR activities. Therefore, it can be concluded that society-oriented CSR activities could improve the repute of the firm, thereby appealing to new customers and increasing their commitment to the business (Branco \& Rodrigues, 2006).

The empirical findings of this study reveal a significant correlation (path coefficient $=0.78 p<0.000$ ) between Market-oriented CSR factors and Customer loyalty of SMEs. This suggests that the more a firm participates in market-oriented CSR initiatives, the higher the chances of attracting and retaining customers. These findings are consistent with those of Ali et al., (2010, p. 2) who confirmed that those SMEs which engaged in market-oriented CSR initiatives were able to advance their social identity and enjoyed enhanced customer loyalty. Correspondingly, the findings of European Commission (2005, p. 6) disclosed that market-oriented CSR initiatives assist SMEs in to attracting and winning the commitment of customers. A survey SMEs in Czech Republic (Polášek, 2010, p. 138) revealed that they had increased customer loyalty as a result of implementing market-oriented CSR activities.

Furthermore, a significant relationship between Environmental-oriented CSR initiatives and Customer loyalty of SMEs was reported and a path coefficient of $0.01(\mathrm{p}<0.000)$ revealed. This suggests that the more a firm supports environmental awareness campaigns and funds sporting and cultural events, the higher the chances of attracting customers who are enthusiastic to continuously supporting the business and recommending its products to potential customers. It should be noted that the findings of this study concur with the results of Kassins and Soteriou (2003, p. 13) which revealed a positive correlation between environmental practices and customer loyalty. Accordingly, the benefits of adopting environmental initiatives include reducing operational costs, prospects for innovation and customer loyalty (Kassins and Soteriou, 2003, p. 13). However, it should be noted that it may be costly for SMEs to invest in environmental-oriented CSR activities. Hence, SMEs can achieve customer loyalty by engaging in specific less costly environmental-oriented CSR activities.

\section{Conclusions and Recommendations}

The study results revealed significant correlations between the CSR activities and Customer loyalty of SMEs. This suggests that the more a firm engages in community initiatives, the higher the chances of attracting and retaining customers. Hence, it is important for SMEs to provide the community with donations and assist the community with general development projects such as education and sports to create and sustain customer loyalty. Society-related CSR activities can also be used as a promotion campaign for SMEs. 
Furthermore, the research results show that Market-oriented CSR factors have a substantial positive influence on Customer loyalty of SMEs. As such, SMEs which care for the consumer requirements by promptly handling customer complaints and treating them justly have more chances of attracting and retaining more customers. Hence, SMEs can increase the loyalty of their customers by treating them honestly and making profit without cheating them. By paying attention to market-oriented CSR activities, SMEs can set new standards; improve their image; provide products that meet and exceed customers' expectations, thus winning their loyalty.

The findings of the study revealed a significant correlation between Environmental-oriented CSR factors and Customer loyalty. This implies that the more SMEs adopt measures that support environmental awareness strategies, the higher the chances of attracting customers who are ready to assist the business and recommend its products to potential customers. Hence, SMEs can achieve customer loyalty by running environmental awareness, ensuring environmental product responsibility and minimising environmental pollution in their localities.

\section{Importance of Findings and Managerial Implications}

The research results are considered supportive of those SMEs that are willing to participate in CSR activities. It is evident that a significant correlation exists between socially responsible businesses and customer loyalty of SMEs. Based on this empirical research, the significances and managerial implications can be drawn. The CSR activities should be considered as a means to attracting and retaining customers by SMEs. Participating in CSR initiatives can be valuable in enhancing customer loyalty of SMEs. As such, SMEs should voluntarily behave in a more responsible manner with the view of attracting and retaining customers. Indeed, results of this study have potential impacts on important SME stakeholders with regard to customer loyalty. SMEs need to properly develop foster positive relationships with their key stakeholders.

Today, businesses have gradually moved from satisfying customers to making them loyal. In this global competitive environment, fostering long-term relationships with key stakeholders is imperative for SME managers. As such, SME managers need to devote their energies to investing in CSR oriented initiatives that are of great importance to communities, customers and environment as a strategy to attract and retain customers. Finally, this study has filled the current research gaps on CSR activities and customer loyalty by contributing to the body of business research with particular emphasis on small and medium-sized enterprises (SMEs) in Uganda.

\section{Limitations and Future Research}

The research findings have substantially contributed to the body of knowledge on CSR factors, particularly in SMEs. However, the study has a few limitations that future academics and researchers could address. The study also presents significant insights to key CSR factors that impact customer loyalty of SMEs. On the basis of these research outcomes, the following areas for further investigation are suggested with regard to CSR factors for SMEs.

The target respondents of this study (SME owners/managers) are a limitation in itself. Given the range of variables proposed in the hypothesised model, different SME stakeholders could have been investigated such as customers and employees. At the same time, the study results cannot be replicated because of the non-probability sampling technique utilised. Additionally, the description of CSR factors in this study is limited to three specific dimensions of CSR factors namely; the community, market place and physical environment. Utilising many constructs which indicate the extent of engagement in CSR initiatives and analysing their influence on customer loyalty would provide greater understanding and appreciation of CSR activities needed for SMEs. Further studies can also be conducted to establish the influence of various CSR initiatives on customer loyalty with a focus on specific industries rather than SMEs in general. Since the study was conducted in one district in Uganda, a comparative study of districts could help address the question of generalisability.

\section{References}

Adapa, S., \& Rindfleish, J. (2013). Corporate Social Responsibility in Small and Medium Sized Accountancy Firms. International Journal of Humanities and Management Sciences, 1(1), 82-87.

Ali, I., Rehman, K. U., Yilmaz, K. U., Nazir, S., \& Ali, J. F. (2010). Effects of corporate social responsibility on consumer retention in cellular industry of Pakistan. African Journal of Business Management, 4(4), $475-485$.

Aqueveque, C., \& Ravasi, D. (2006). Corporate Reputation, Affect and Trustworthiness: An explanation for the reputation-performance relationship. Universita Commerciale LuigiBocconi, Milan, Italy Via San Francesco. 
Arıkan, E., \& Güner, S. (2013). The impact of corporate social responsibility, service quality and customer-company identification on customers. Procedia-Social and Behavioural Sciences, 99, 304-313. https://doi.org/10.1016/j.sbspro.2013.10.498

Asaad, A. (2010). The role of brand equity in the effects of corporate social responsibility on consumer loyalty. Unpublished master's diss. Universiti Sains Malaysia, Malaysia.

Asatryan, R. (2012). The effect of CSR initiatives on customer loyalty in the airline industry. Mathematics and Computers in Contemporary Science, Tomas Bata University in Zlin, Czech Republic.

Ayanda, A. M., \& Laraba, A. S. (2011). Small and Medium Scale Enterprises as a Survival Strategy for Employment Generation in Nigeria. Journal of Sustainable Development, 4(1), 200-206.

Baker, J. (2001). Remarks of Jim Baker, International Confederation of Free Trade Unions, to Organisation for Economic Co-operation and Development. Paper presented at the Conference on Corporate Social Responsibilities, Paris, France. 19 June.

Bellihi, H., \& Bazi, M. (2015). Role of SMEs in the economic and social development: Case of Terroir Products in Souss Massa Draa Region (Morocco). Advances in Economics and Business, 3(8), 340-347. https://doi.org/10.13189/aeb.2015.030807

Bhattacharya, C. B., \& Sen, S. (2004). When, why, and how consumers respond to social initiatives. California Management Review, 47(1), 9-24. https://doi.org/10.2307/41166284

Branco, M. C., \& Rodrigues, L. L. (2006). Corporate social responsibility and resource-based perspectives. Journal of Business Ethics, 69, 111-132. https://doi.org/10.1007/s10551-006-9071-z

Brimpong, M. A. (2008). The Effect of Customer Satisfaction on Loyalty. A case study of the First Allied Savings and Loans Ltd. Unpublished master dissertation, Kwame Nkrumah University of Science and Technology.

Burton, B., \& Goldsby, M. (2009). Corporate Social Responsibility Orientation, Goals and Behaviour: A Study of Small Business Owners. Business \& Society, 48(1), 88-104. https://doi.org/10.1177/0007650307305367

Cabeza García, L., Sacristán Navarro, M., \& Gómez Ansón, S. (2014). Propiedad familiar, control y efecto generación y RSC. Revistade Empresa Familiar, 4(1), 9-20.

Cengiz, E., Ayyildiz, H., \& Er, B. (2007). Effects of image and advertising efficiency on customer loyalty and antecedents of loyalty: Turkish banks sample. Banks and Bank Systems, 2(1), 56-78.

Chen, X. (2009). Social responsibility is the ethical foundation of public relations. Chinese: Journal of International Public Relations, 3, 93.

Ciliberti, F., Pontrandolfo, P., \& Scozzi, B. (2008). Investigating Corporate Social Responsibility in Supply Chains: A SME Perspective. Journal of Cleaner Production, 16, 1579-88. https://doi.org/10.1016/j.jclepro.2008.04.016

Donnelly, M. (2009). Building Customer Loyalty. A Customer Experience Based Approach in a Tourism Context. Unpublished doctoral thesis, Waterford Institute of Technology.

European Commission. (2005). The new SME definition. User guide and model declaration. European. 1 January 2005.

Gable, M., Fiorito, S. S., \& Topol, M. T. (2008). An empirical analysis of the components of retailer customer loyalty programs. International Journal of Retail \& Distribution Management, 36(1), 32-49. https://doi.org/10.1108/09590550810846983

Grant, M. (2000). Contemporary strategy analysis (3rd ed.). Massachusetts: Blackwell Publisher.

Grewal, H. (2012). "Why are Companies Engaging in CSR Initiatives?” National Conference on Emerging Challenges for Sustainable Business 2012, Shree Satya Institute of Management, Moradabad.

Hafeez, S., \& Muhammad, B. (2012). The Impact of Service Quality, Customer Satisfaction and Loyalty Programs on Customer's Loyalty: Evidence from Banking Sector of Pakistan. International Journal of Business and Social Science, 3(16), 200-209.

Hair, J. F., Black, W. C., Babin, J. B., Anderson, R. E., \& Tatham, R. L. (2006). Multivariate data analysis (6th ed.). Upper Saddle River, New Jersey: Pearson/Prentice Hall.

Herpen, E., Meulenberg, M., \& Pennings, J. (2003). Consumers' Evaluations of Socially Responsible Activities in Retailing. Mansholt Working Paper, Mansholt Graduate School of Social Sciences, Wageningen 
University, 2003.

Heyder, M., \& Theuvsen, L. (2009). Corporate Social Responsibility in Agribusiness: Empirical Findings from Germany, European Association of Agricultural Economists European Association of Agricultural Economists, 113th Seminar, Chania, Crete, Greece.

Hoe, S. L. (2008). Issues and Procedures in Adopting Structural Equation Modeling Technique. Journal of Applied Quantitative Methods, 3(1), 76-83.

Howard-Grenville, J. A., \& Hoffman, A. J. (2003). The importance of cultural framing to the success of social initiatives in business. Academy of Management Executive, 17(2), 70-84. https://doi.org/10.5465/ame.2003.10025199

Hsueh, C. (2012). Collaboration on Corporate Social Responsibility between Suppliers and a Retailer. Proceedings of the World Congress on Engineering Vol III, London, U.K.

Inyang, B. J. (2013). Defining the role engagement of small and medium-sized enterprises in corporate social responsibility. International Business Research, 6(5), 123-132. https://doi.org/10.5539/ibr.v6n5p123

Kang, J., \& Hustvedt, G. (2014). Building trust between consumers and corporations: The role of consumer perceptions of transparency and social responsibility. Journal of Business Ethics, 125(2), 253-265. https://doi.org/10.1007/s10551-013-1916-7

Kassins, G. I., \& Soteriou, A. C. (2003). Greening the Service Profit Chain: The Impact of Environmental Management Practices. Journal of Production and Operations Management, 12(3), 386-402. https://doi.org/10.1111/j.1937-5956.2003.tb00210.x

Kotler, P., \& Armstrong, G. (2008). Principles of marketing (12th ed.). Englewood Cliffs, NJ: Prentice-Hall.

Kumar, T. P., \& Priyadharshini, K. (2013). The Effects of Corporate Social Responsibility on Consumer Behaviour With Reference to Public Sector Bank (Chennai). Tenth AIMS International Conference on Management, January 6-9, 2013.

Lam, R., \& Burton, S. (2006). SME banking loyalty and disloyalty: a qualitative study in Hong Kong. International Journal of Bank Marketing, 24(1), 37-52. https://doi.org/10.1108/02652320610642335

Lee, J., Lee, J., \& Feick, L. (2001). The impact of switching costs on the customer satisfaction-loyalty link: mobile phone service in France. Journal of Services Marketing, 15(1), 35-48. https://doi.org/10.1108/08876040110381463

Longinos, M., \& Salvador, R. (2007). I need you too! Corporate identity attractiveness for consumers and the role of social responsibility. Journal of Business Ethics, 71(3), 245-260. https://doi.org/10.1007/s10551-006-9137-y

Longo, M., Mura, M., \& Bonoli, A. (2005). Corporate social responsibility and corporate performance: the case of Italian SMEs. Corporate Governance, 5(4), 28-42. https://doi.org/10.1108/14720700510616578

Maheshwari, V., Lodorfos, G., \& Jacobsen, S. (2014). Determinants of brand loyalty: A study of the experience-commitment-loyalty constructs. International Journal of Business Administration, 5(6), 13-23. https://doi.org/10.5430/ijba.v5n6p13

Maignan, I., \& Ferrell, O. C. (2004). Corporate social responsibility and marketing: An integrative framework. Journal of the Academy of Marketing Science, 32(1), 3-19. https://doi.org/10.1177/0092070303258971

Mandhachitara, R., \& Poolthong, Y. (2011). A model of customer loyalty and corporate social responsibility. Journal of Services Marketing, 25(2), 122-133. https://doi.org/10.1108/08876041111119840

Mandl, I. (2009). The Interaction between Local Employment Development and Corporate Social Responsibility, Austrian Institute for SME Research, Elise Crunel, Vienna, January 2009.

Mandl, I., \& Dorr, A. (2007). CSR and Competitiveness. European SMEs' Good Practice, Consolidated European Report, Vienna.

Mbabazi, A. (2012). Speech read at the Uganda Top 100 Mid-Size Companies-Gala Dinner at Serena Hotel, Kampala on 23 November 2012.

McDonald, L. M., \& Rundle-Thiele, S. (2008). Corporate social responsibility and bank customer satisfaction. International Journal of Bank Marketing, 26(3), 170-182. https://doi.org/10.1108/02652320810864643

Munasinghe, M. A. T. K., \& Malkumari, A. P. (2012). Corporate Social Responsibility in Small and Medium 
Enterprises (SME) in Sri Lanka. Journal of Emerging Trends in Educational Research and Policy Studies, 3(2), 168-172.

Nejati, M., \& Amran, A. (2009). Corporate social responsibility and SMEs: Exploratory study on motivations from a Malaysian perspective. Journal of Business Strategy Series, 10(5), 259-265. https://doi.org/10.1108/17515630910989150

Ngui, T. K. (2014). The role of SMEs in employment creation and economic growth in selected Countries. International Journal of Education and Research, 2(12), 461-472.

Núñez, G. (2008). Promoting corporate social responsibility in small and medium enterprises in the Caribbean: survey results. United Nations Publications, Washington.

Ochoti, G. N., Muathe, S., Ronoh, P. K., Maronga, E., \& Ochoti, F. O. (2013). Corporate Social Responsibility, Client Satisfaction and Competitive advantage in retail banking institutions in Kenya. International Journal of Arts and Commerce, 2(2), 161-173.

Ouyang, Y. (2010). A Relationship between the Financial Consultants' Service Quality and Customer Trust after Financial Tsunami. International Research Journal of Finance and Economics, 36(2010), 75-86.

Pakseresht, A. (2010). Brand equity and corporate responsibility: A review of brand valuation methods. Retrieved from http://www.essays.se/essay/9e20739689/

Perrini, F., \& Minoja, M. (2008). Strategizing corporate social responsibility: Evidence from an Italian medium-sized, family owned company. Business Ethics: A European Review, 17(1), 47-63. https://doi.org/10.1111/j.1467-8608.2008.00519.x

Pirithiviraj, J. C. D., \& Kajendra, K. (2010). Relationship between Market Orientation andCorporate Social Responsibility with special reference to Sri Lankan Financial Sector. Journal of Emerging Trends in Economics and Management Sciences, 1(2), 107-113.

Pirsch, J., Gupta, S., \& Grau, S. L. (2007). A framework for understanding corporate social responsibility programs as a continuum: An exploratory study. Journal of Business Ethics, 70(2), 125-140. https://doi.org/10.1007/s10551-006-9100-y

Polášek, D. (2010). Corporate Social Responsibility in Small and Medium-Sized Companies in the Czech Republic. Unpublished doctoral thesis, Czech Management Institute Praha.

Putnam, R. (2000). Bowling alone: The collapse and revival of the American community (New York, NY: Simon and Schuster). https://doi.org/10.1145/358916.361990

Raman, M., Lim, W., \& Nair, S. (2012). The impact of corporate social responsibility on consumer loyalty. Kajian Malaysia, 30(2), 71-93.

Ramzi, A.R. \& Mohamed, B. (2010). Customer Loyalty and the Impacts of Service Quality: The Case of Five Star Hotels in Jordan. International Journal of Human and Social Sciences, 5(13), 886-892.

Rehman, M. (2012). Relationship among corporate image, intangible perceived quality, choosing, habit and customer loyalty. Management \& Marketing, 10(1), 183-197.

Sen, S., Bhattacharya, C. B., \& Korschun, D. (2006). The role of corporate social responsibility in strengthening multiple stakeholder relationships: A field experiment. Journal of the Academy of Marketing Science, 34(2), 158-166. https://doi.org/10.1177/0092070305284978

Singhal, P. (2013). Leveraging Dimensions of CSR to Enhance Competitiveness of Small and Medium Enterprises. International Journal of Humanities and Management Sciences, 1(1), 77-81.

Somyot, W. (2008). The Evaluation of Service Quality by Socially Responsible Customers. Unpublished doctoral thesis, Virginia Polytechnic Institute and State University.

Stanisavljević, M. (2017). Does Customer Loyalty Depend on Corporate Social Responsibility? Our Economy, 63(1), 38-46. https://doi.org/10.1515/ngoe-2017-0004

Stoian, C., \& Gilman, M. (2012). Corporate social responsibility that 'pays': A strategic approach to CSR for SMEs. Working Paper No. 255, University of Kent.

Suhr, D., \& Shay, M. (2009). Guidelines for Reliability, Confirmatory and Exploratory Factor Analysis. Retrieved from http://www.wuss.org/proceedings09/09WUSSProceedings/.../ANL-SuhrShay

Sweeney, L. (2007). Corporate social responsibility in Ireland: Barriers and opportunities experienced by SMEs 
when undertaking CSR. Corporate $\quad$ Governance, $\quad 7(4), \quad$ 516-523. https://doi.org/10.1108/14720700710820597

Szabo, A. (2008). The Corporate Social Responsibility: An Opportunity for SMEs. Retrieved from http://www.unglobalcompact.org/http://www.unece.org/indust/sme/

Szlávik, J., Pálvölgyi, T., Csigéné Nagypál, N., \& Füle, M. (2006). Sector Survey on CSR in SMEs of the Automotive Supply Chain in Hungary and Austria.

Timo, C. (2006). Corporate Social Responsibility in Dutch SMEs: Motivations and CSR Stakeholders. Unpublished doctoral thesis, Maastricht University, Maastricht.

Turyakira, P. (2012). Corporate social responsibility: A competitive strategy for small and medium-sized enterprises in Uganda. Unpublished doctoral thesis, Nelson Mandela Metropolitan University.

Tushabomwe, C. K. (2010). Small and Medium-Sized Enterprises in East Africa. The African Executive, 280.

Tusubira, N. F., \& Nabeta, I. N. (2013). Income Tax Compliance among SMEs in Uganda: Taxpayers' Proficiencies Perspective. International Journal of Business and Social Science, 4(11), 133-143.

Uganda Bureau of Statistics (UBOS). (2007) Business Register Update. A report covering all the sectors of the economy except the Public sector.

Vives, A. (2005). Social and Environmental Responsibility in Small and Medium Enterprises in Latin America. Journal of Corporate Citizenship, 21, 39-50.

Williamson, D., Lynch-Wood, G., \& Ramsay, J. (2006). Drivers of environmental behaviour in manufacturing SMEs and the implications for CSR. Journal of Business Ethics, 67(3), 317-330. https://doi.org/10.1007/s10551-006-9187-1

Yusof, J. M., Manan, H. A., Karim, N. A., \& Kassim, N. A. M. (2015). Customer's Loyalty Effects of CSR Initiatives. Paper presented at the Asian Conference on Environment-Behaviour Studies, Chung-Ang University, Seoul, South Korea. https://doi.org/10.1016/j.sbspro.2015.01.020

\section{Copyrights}

Copyright for this article is retained by the author(s), with first publication rights granted to the journal.

This is an open-access article distributed under the terms and conditions of the Creative Commons Attribution license (http://creativecommons.org/licenses/by/4.0/). 